\title{
Polycyclic Aromatic Hydrocarbons in Soils in Industrial Areas: Concentration and Risks to Human Health
}

\author{
Ljiljana Stojanović Bjelić1, Dragana Nešković Markić1, Predrag Ilić2*, \\ Zia Ur Rahman Farooqi ${ }^{3}$ \\ ${ }^{1}$ Pan-European University “Apeiron”, Pere Krece 13, Banja Luka, Republic of Srpska, Bosnia \& Hercegovina \\ ${ }^{2}$ PSRI Institute for Protection and Ecology of the Republic of Srpska, Vidovdanska 43, \\ Banja Luka, Republic of Srpska, Bosnia and Herzegovina \\ ${ }^{3}$ Institute of Soil and Environmental Sciences, University of Agriculture, Faisalabad-38040, Pakistan
}

Received: 16 February 2021

Accepted: 19 May 2021

\begin{abstract}
Soil samples were collected in an industrial area (Banja Luka, Bosnia and Herzegovina) and analyzed the concentration of 16 polycyclic aromatic hydrocarbons (PAHs). The total concentration of 16 PAHs in surface soil varied within the range of $0.599-2.848 \mathrm{mg} / \mathrm{kg}$ and in deeper layer soil samples $0.041-0.320 \mathrm{mg} / \mathrm{kg}$. Two basic sources of PAHs at this location are: pyrogenic and petrogenic sources. Benzo(a)pyrene toxic equivalency factors (TEFs) were used to calculate BaPeq in order to evaluate carcinogenic risk of soil contamination with PAHs. The total BaPeq of seven carcinogenic PAHs in surface soil and deeper soil layer were in the range $23.270-368.63 \mu \mathrm{g} / \mathrm{kg}$ (mean of $151.223 \mu \mathrm{g} / \mathrm{kg}$ ), and 15.71-80.24 $\mu \mathrm{g} / \mathrm{kg}$, (mean of $48.08 \mu \mathrm{g} / \mathrm{kg}$ ), respectively. These indicated that PAHs in this industrial soil presented relatively high toxicity potential. This study identifies the concentration and estimation of the potential cancer risk caused by contact with soils for adults, adolescents and children. In accordance with the estimated values of incremental life cancer risks (ILCRs), the cancer risk resulting from contact with the contaminated surface soil should be considered high (total ILCR $>10^{-3}$ ). The results suggest that current PAHs concentration highly carcinogenic and may hold a serious health risk for local residents and employees.
\end{abstract}

Keywords: Banja Luka, human health risk, ILCRs (incremental life cancer risks), polycyclic aromatic hydrocarbons (PAHs), soil

*e-mail: predrag.ilic@institutzei.net 


\section{Introduction}

Polycyclic aromatic hydrocarbons (PAHs) are an important group of environmental organic pollutants. PAHs are introduced into the environment from natural and anthropogenic sources. Natural sources are forest fires and volcanic activity but dominant anthropogenic sources are petrochemical industrial effluents, combustion processes and coal tar processing waste [1]. Hundreds of these compounds exist in the environment. The United States Environmental Protection Agency singled out 16 of those as major pollutants that should be strictly controlled, routinely analyzed and monitored [2, 3]. PAHs are not easily degraded in the environment [4], and they can cause various toxic impact to humans and wildlife [5]. These organic compounds are primarily emitted into the atmosphere, and by their transport over smaller or greater distances, they accumulate in the soil by deposition $[6,7]$. A study in the UK found that at least $90 \%$ of total environmental PAHs are accumulated in soil [8]. These harmful pollutants accumulated in urban soil can be transferred to surface/groundwater by precipitation and urban runoff, evaporate into the atmosphere by evaporation and transported to crops from polluted soil and air by adsorption of roots and leaves, which can indirectly result in further water, atmosphere and food pollution. [9]. Studies by Menzi et al. (1992) [10] and Nadal et al. (2004) [11] showed far greater exposure of humans to PAHs through soil than through water and air.

The total global atmospheric emissions of 16 PAHs in 2007 were estimated to be 504 giga grams per year, with residential/commercial biomass burning (60.5\%), open-field biomass burning (agricultural waste burning, deforestation, and wildfire, 13.6\%), and petroleum consumption by on-road motor vehicles (12.8\%) [12]. The emission of PAHs in Bosnia and Herzegovina $(\mathrm{BiH})$ is estimated at $4,800 \mathrm{~kg} /$ year in 2012 , that is $2,700 \mathrm{~kg} \mathrm{BaP}$ in $2012,2,500 \mathrm{~kg} \mathrm{BaP}$ in 2013 and 2,300 kg BaP in 2014 [13]. The highest concentrations of PAHs are found in areas with increased human activity [14]. Its high hydrophobicity and stabile chemical structure is the cause of PAHs insolubility, and thusly, they are adsorbed rapidly in soil organic matter [15]. PAHs are receiving extensive attention because of their adverse effects on human health including high toxicity, mutagenicity and carcinogenicity $[16,17]$ as well as the real danger of PAHs entering the food chain [18]. Several PAHs such as benzo[a]-pyrene $(\mathrm{BaP})$ and benzo[a]anthracene $(\mathrm{BaA})$ are carcinogenic and some are the precursor to carcinogenic daughter compounds such as benzo[b] fluoranthene (BbF) [19]. Additionally, PAHs can also pose risk to the public through inhalation of dust and from soil and water by direct ingestion and dermal contact [20]. The physicochemical properties of PAHs make them highly mobile in the environment, allowing them to distribute across air, soil, and water bodies
[21]. By emitting PAHs sources into the air, they are distributed between the gaseous, particulate and droplet phases. Wind-borne PAHs are easily transported by air over long distances, crossing national borders. PAHs from the air are deposited on the surface of the land, in water surfaces as well as on the surface of roads. From land and roads, especially near the source of PAHs, these pollutants carried by precipitation and rainwater reach aquatic ecosystems, i.e. they are deposited and concentrated in sedimentary layers [22]. Mixtures of PAHs may be more carcinogenic to humans than individual PAHs.

The acute or short-term health effects of PAHs on human health will depend mainly on the extent of exposure, the concentration of PAHs during exposure, the toxicity of the PAHs, and the route of exposure (inhalation, ingestion, or dermal contact) [21]. Occupational exposure to high levels of pollutant mixture containing PAHs results in symptoms such as eye irritation, nausea, vomiting, diarrhea, and confusion [23]. Health effects from long-term or chronic exposure to PAHs may include decreased immune function, cataracts, kidney and liver damage, breathing problems, asthma-like symptoms, and lung function abnormalities [24].

PAHs were included as priority pollutant lists of the Agency of Toxic Substances and Disease Register (ATSDR), the International Agency for Research on Cancer (IARC), the Environmental Protection Agency (EPA), and Stockholm Convention due to their mutagenic and carcinogenic properties.

The PAHs included in the carcinogenic groups according to the IARC: 1 - carcinogenic to humans benzo[a]-pyrene $(\mathrm{BaP}) ; 2 \mathrm{~A}$ - probably carcinogenic to humans dibenz[a,h]anthracene (DahA); 2B possibly carcinogenic to humans naphthalene (Nap), benzo[a]anthracene $(\mathrm{BaA})$, chrysene $(\mathrm{Chr})$, benzo[b] fluoranthene $(\mathrm{BbF})$, benzo[k]fluoranthene $(\mathrm{BkF})$, indeno[1,2,3-cd]pyrene (IcdP); 3 - not classifiable as to its carcinogenicity to humans acenaphthylene (Acy), acenaphthene (Ace), fluorene (Flo), phenanthrene (Phe), anthracene (Ant), fluoranthene (Fluo), pyrene (Pyr), benzo[a]anthracene (BghiP) [25].

A human health risk assessment is the process to estimate the probability of adverse health effects on humans exposed to chemical pollutants in contaminated living environment, nowadays and in the future [15]. Potential carcinogenic risks on those who work and live in the vicinity of the industrial complex could very likely be due to prolonged contact to contaminated soil. Exposure to PAHs in the soil can occur through: (1) ingestion of substrate particles; (2) dermal absorption of pollutants in particles adhered to exposed skin; (3) inhalation of re-suspended particles from soil.

Reactive metabolites of some of the PAHs have the potential to bind to cellular protein and DNA, resulting in biochemical disruption and cell damage leading to mutations, malformations, tumors, and cancers. [21, 26]. To date, occupational exposure studies of PAHs have 
confirmed the risk of developing the most common skin cancers [27, 28], lung [29, 30], colorectal cancer [31], and effects on the immune system, neurotoxicity and reproductive toxicity [32-34].

Few studies have reported PAHs levels in ambient air in $\mathrm{BiH}[35,36]$. Škarek et al. (2007) [35] investigated the concentration of PAHs in urban air in two industrial cities (Sarajevo and Tuzla). The De Pieri et al. (2014) [36] study investigated the levels, sources and day/night variations and human inhalation risk in urban air PAHs in Sarajevo. The concentration of the sum of 16 PAHs in Tuzla was between $58-121 \mathrm{ng} / \mathrm{m}^{3}$, while in Sarajevo it was between 22-50 $\mathrm{ng} / \mathrm{m}^{3}$ [35], that is $10.7-172 \mathrm{ng} / \mathrm{m}^{3}$ in the gaseous phase and $0.7-108.5 \mathrm{ng} / \mathrm{m}^{3}$ in particulate phase [36]. Concentrations of these parameters in the air are higher than the values of other European cities, e.g. Naples, Italy $\left(22.7 \mathrm{ng} / \mathrm{m}^{3}\right)$ [37], Flanders, Belgium ( $93 \mathrm{ng} / \mathrm{m}^{3}$ ) [38], and Augsburg, Germany (1.34-11 ng/m³ [39].

By analyzing POPs in the Neretva River $(\mathrm{BiH})$, the concentrations of sum 16 PAHs ranged from 160 to $4,000 \mathrm{pg} / \mathrm{L}$ [40], that is the values of benzo(a) pyrene were less than $0.1 \mu \mathrm{g} / \mathrm{L}$ which meets the requirements for the maximum permitted concentration of this substance in surface waters [41].

In addition, a comparison of mean $\Sigma \mathrm{PAHs}$ concentrations in soils from different cities worldwide is given in Table 1. Samples of rural soil, outside the zone, i.e. in the reduced zone of anthropogenic impact, showed far lower results of PAHs, while values in urban soil recorded high concentrations of PAHs. These results suggest that people, especially in urban and industrial centers, must be familiar with the quality of the environment.

Currently, there is very little data on soil pollution in $\mathrm{BiH}$, but preliminary studies show a high level of PAHs in urban and industrial soil. Šapčanin et al. (2017) [45] found that the values of sum 16 PAHs in the soil at children's playgrounds in Sarajevo $(\mathrm{BiH})$ ranged from 0.184 to $7.983 \mathrm{mg} / \mathrm{kg}$. In European countries such as Switzerland, the sum of 16 PAHs ranged from
0.05-0.62 $\mathrm{mg} / \mathrm{kg}$ [46], in urban soil in Italy $0.007-0.755 \mathrm{mg} / \mathrm{kg}$ [47]. Ilić et al. (2021) [48] determined values during previous research in this post-industrial complex which ranged from 0.356 to $11.49 \mathrm{mg} / \mathrm{kg}$, with mean values of $1.99 \mathrm{mg} / \mathrm{kg}$.

As of today, in $\mathrm{BiH}$, there are no published studies on PAHs and corresponding health risk assessments. Despite the fact that the first studies of PAHs analysis in $\mathrm{BiH}$ were conducted in 2007 , very little has been done to assess the risk to human health, remediation measures, and elimination of emission sources.

Various methodologies have been created for surveying the risk of PAHs. Heath risk assessment of carcinogenic PAHs cannot be related only to overall concentration. Rather, each PAH has a different carcinogenic potential [49]. The widely used method to assess the human health associated with PAHs is incremental lifetime cancer risk (ILCR). It is based on standard USEPA model used to quantitatively estimate the risk exposure to PAHs in soil [50].

The aim of this study is to determine the level of PAHs contamination in soils, and evaluate the health risks using ILCR for the population living in the vicinity of industrial complex (locality Incel - former Cellulose Factory) in the city of Banja Luka, Republic of Srpska, BiH. This study can hopefully offer valuable insight and critical information that can be used for soil remediation, health risk mitigation and give guidelines for future urban planning in former industrial complex.

\section{Experimental}

\section{Study Area}

The city of Banja Luka is the main administrative center of the Republic of Srpska entity, situated in the northwest part of $\mathrm{BiH}$. It spans over $1,238.91 \mathrm{~km}^{2}$, and has a population of 185000 . The city has a typical continental climate, hot summers with abundant precipitation (avg. July temp $21.3^{\circ} \mathrm{C}$ ) and very cold

Table 1. Concentration comparison of PAHs in soil from different cities.

\begin{tabular}{|c|c|c|c|c|c|}
\hline Country, city & Soil types & Depth $(\mathrm{cm})$ & Number of PAHs & Mean (mg/kg) & References \\
\hline Portugal, Lisbon & Urban & $0-10$ & 16 & 1.544 & {$[6]$} \\
\hline United Kingdom, Glasgow & Urban & $0-10$ & 15 & 11.930 & [42] \\
\hline Italy, Torino & Urban & $0-10$ & 15 & 1.990 & [42] \\
\hline Slovenia, Ljubljana & Urban & $0-10$ & 15 & 0.989 & [42] \\
\hline \multirow{3}{*}{ Serbia, Belgrade } & Rural & $0-10$ & 16 & 0.018 & \multirow{3}{*}{ [43] } \\
\hline & Recreational & $0-10$ & 16 & 0.298 & \\
\hline & Urban & $0-10$ & 16 & 0.375 & \\
\hline Sweden, Stockholm & Urban & $10-20$ & 15 & 4.836 & [44] \\
\hline China, Dongjiang River Basin & Rural & $0-20$ & 17 & 0.116 & [19] \\
\hline
\end{tabular}


winters (avg. January temp $-0.8^{\circ} \mathrm{C}$ )

The subject of research of this study is Incel, postindustrial complex located on the east bank of Vrbas river, some $3 \mathrm{~km}$ from the Banja Luka center. This postindustrial complex is located on the right bank of the river Vrbas in the alluvial plain. The composition of the surface layer is dominated by gray and gray-yellow clays, humic and fatty clays. Gravel clays are dominant in deeper layers $(>2 \mathrm{~m})$ [51].

Industrial complex Incel was built in 1954 and manufactured cellulose, viscose and paper products. The total area of this industrial complex is 80 ha. The complex also had separate electrolysis and power plant. The complex was structured as a large conglomerate, typical for socialist countries of the time, and was fully operational up until the Balkan Wars in 1992. Most industry collapsed during the war, and the recent economic recession in $\mathrm{BiH}$ resulted in lower production or complete shutdown. In turbulent times during and after the war, late $20^{\text {th }}$ century, the majority of the equipment and machinery was destroyed, sold or vandalized. This economic downturn has resulted in a decrease in harmful emissions to the environment [36]. The industrial complex was turned into a business zone and was opened to leasing, with about 60 small companies using the space, mostly as warehouses, employing around 1,500 workers. Near this industrial complex there is a city heating plant on biomass and diesel fuel oil. Until a couple of years ago, this city heating plant used only diesel fuel oil as an energy source. A big problem, especially during the winter months, are individual fireplaces or heating systems in households where citizens burn wood and coal of poor quality and even railway sleepers that have been treated with burnt oil due to the poor socio-economic situation. Depending on the type of wood, polycyclic aromatic compounds (PAH), polychlorinated biphenyls
(PCB), polychlorinated dibenzo-p-dioxins (PCDD), and polychlorinated dibenzofurans (PCDF) can also be released [52, 53]. There is a well-developed traffic infrastructure inside and around this industrial complex. Around the industrial complex there are households that often burn weeds and plants in spring and autumn, i.e. prepare the land for sowing. In the last couple of years, newly built residential/commercial units have been added directly on the lands of and the surrounding area of the industrial complex.

\section{Sampling and Analysis}

During August 2019, soil samples were collected from four locations in the industrial complex, from different layers of soil: surface (depth of $30 \mathrm{~cm}$ ), and in deeper layer $(30-400 \mathrm{~cm})$. Sampling borehole depths were $3.5 \mathrm{~m}, 3 \mathrm{~m}, 3.5 \mathrm{~m}$ and $4 \mathrm{~m}$, respectively, with diameter of $121 \mathrm{~mm}$. Drilling, sample collection, their storage and transport, were performed by licensed laboratory (Fig. 1).

In the laboratory, soil samples were dried at room temperature, and impurities such as roots and stones were removed. The PAHs from soil samples were extracted using ultrasound-assisted extraction according to the US Environmental Protection Agency (USEPA) 3550C method [54]. Soil samples (1 g) were mixed with $\mathrm{Na}_{2} \mathrm{SO}_{4}$ anhydride $(2 \mathrm{~g})$ and added solvent (acetone: dichloromethane, 1:1, v:v); the sample vessel was then transferred to an ultrasonic bath for 15 minutes extraction. Subsequently, the samples were decanted after centrifugation at $7000 \mathrm{r} / \mathrm{min}$ for $10 \mathrm{~min}$. The extraction process was repeated three times. An alumina/silica gel column was used to clean up the extract. The PAHs were eluted with dichloromethane and n-hexane (2:3, v:v). The eluate was concentrated to $0.2 \mathrm{~mL}$ under a gentle

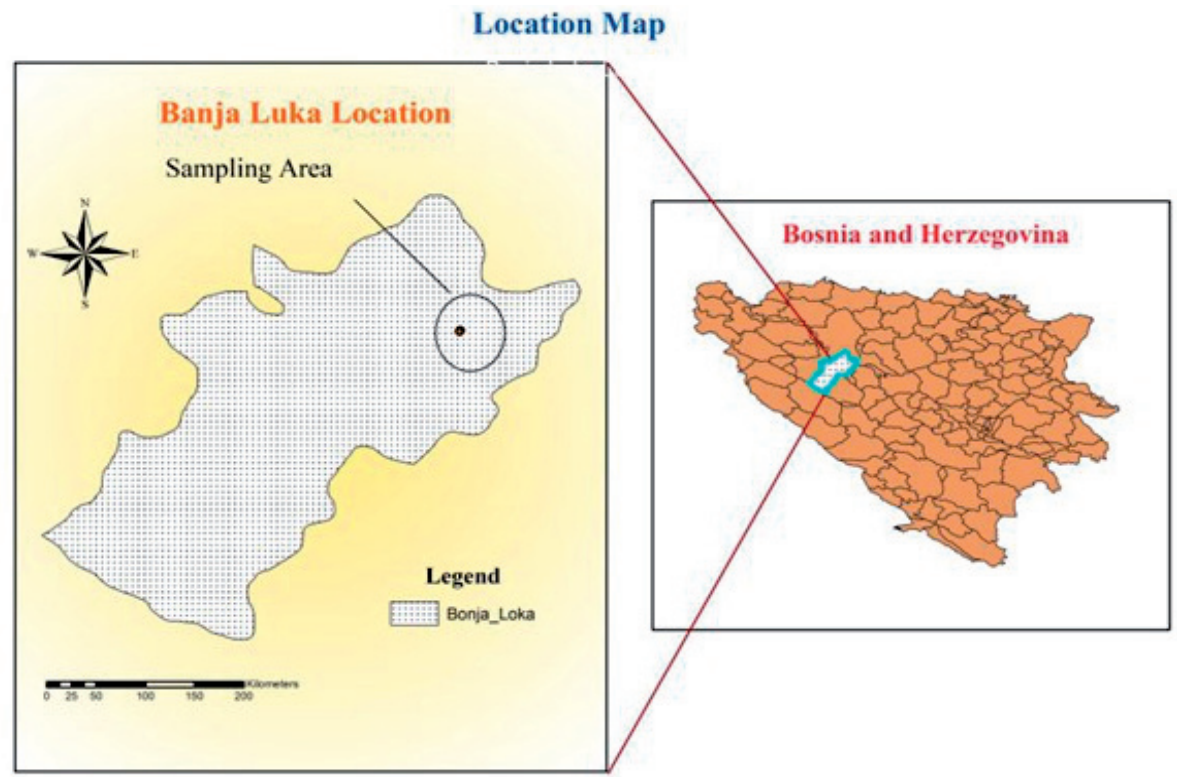

Fig. 1. Map of the sampling sites in industrial area, Banja Luka (B\&H). 
nitrogen stream.

Soil samples were analyzed for 16 PAHs designated as apriority by (USEPA), according to USEPA Method 8270D [55]. The analysis was carried out using a gas chromatograph equipped with a mass spectrometer (GC/MS). PAHs were identified by comparison of retention times and spectra of reference compounds. Accredited quantification limit for $\mathrm{PAH}$ in soil is $0.02 \mathrm{mg} / \mathrm{kg}$.

Components of PAHs that were analyzed were: low molecular weight PAHs (LMWPAHs) with 2 and 3 aromatic rings (Nap (2-ring), Acy (3-ring), Ace (3-ring), Flo (3-ring), Phe (3-ring), Ant (3-ring)) and high molecular weight PAHs (HMWPAHs) with 4-6 aromatic rings (Fluo (4-ring), Pyr (4-ring), BaA (4-ring), $\mathrm{Chr}$ (4-ring), $\mathrm{BbF}$ (5-ring), $\mathrm{BkF}$ (5-ring), $\mathrm{BaP}$ (5-ring), IcdP (6-ring), DahA (5-ring) and BghiP (6-ring)). According to te US EPA [56] seven PAHs compounds have been classified as probable human carcinogens: $\mathrm{BaA}, \mathrm{Chr}, \mathrm{BbF}, \mathrm{BkF}, \mathrm{BaP}$, IcdP and DahA [57].

In 2016, 239,000 people in the EU-27 died of lung cancer, i.e. $20.5 \%$ of all cancer-related deaths. In 2016 , the EU-28 standardized death rate for lung cancer was 52.9 per 100,000 inhabitants. Surrounding countries, Serbia and Croatia recorded 69.3 i.e. 68.4 deaths per 100,000 inhabitants, respectively. Finland, Sweden, and Portugal were the only Member States to record standardized death rates for lung cancer below 40.0 per 100.000 inhabitants [58]. The International Agency for Research on Cancer in its report for 2018 presents data on new cases of cancer in $\mathrm{BiH}$ : lung (16.9\%), colorectum $(12.6 \%)$, breast $(9.6 \%)$, prostate $(6.5 \%)$, stomach $(5 \%)$ and other (49.4\%) [59].

About $27 \%$ of deaths in $\mathrm{BiH}$ are related to the environment, i.e. $\mathrm{BiH}$ and Albania have the highest rates in Europe. BiH's rate of deaths related to air pollution, environmental-noise-related heart disease [60].

In 2017, thirteen EU-27 Member States recorded $\mathrm{BaP}$ concentrations above $1.0 \mathrm{ng} / \mathrm{m}^{3}$, especially Central and Eastern European countries (Poland and the Czech Republic), while values below $0.12 \mathrm{ng} / \mathrm{m}^{3}$ were recorded in Cyprus, the Netherlands and Sweden. In Croatia, the country with which $\mathrm{BiH}$ borders (because $\mathrm{BiH}$ is not a member of the EU and therefore does not have these data), this value was above $1.0 \mathrm{ng} / \mathrm{m}^{3}$ [61].

\section{Methodology Risk Assessment of PAHs}

The incremental life cancer risks (ILCRs) was used to quantitatively estimate the exposure risk for environmental PAHs based on Exposure Factors Handbook from USEPA [2]. The following formulas were used to assess different groups' ILCR through ingestion, dermal and inhalation:

$$
\text { ILCRS }_{\text {Ingestion }}=\frac{\operatorname{CS} \times\left(\operatorname{CSF}_{\text {Ingestion }} \times \sqrt[3]{\left(\frac{B W}{70}\right)}\right) \times \operatorname{IR}_{\text {Ingestion }} \times \text { EF x ED }}{B W \times A T \times 10^{6}}
$$

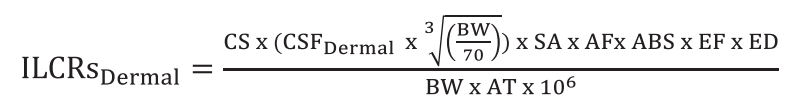

ILCRs $_{\text {Inhalation }}=\frac{\mathrm{CS} \times\left(\mathrm{CSF}_{\text {Inhalation }} \times \sqrt[3]{\left(\frac{\mathrm{BW}}{70}\right)}\right) \times \mathrm{IR}_{\text {Inhalation }} \times \mathrm{EF} \times \mathrm{ED}}{\mathrm{BW} \times \mathrm{AT} \times \mathrm{PEF}}$

$\mathrm{CS}$ - is the PAH concentration in soil $(\mu \mathrm{g} / \mathrm{kg})$ based on toxic equivalents of $\mathrm{BaP}$ using the toxic equivalency factor (TEF). The TEFs for NaP, Acy, Ace, Flu, Phe, Ant, Flt, Pyr, BaA, Chr, BbF, BkF, BaP, DBA, InP, and BghiP are 0.001, 0.001, 0.001, 0.001, 0.001, 0.01, 0.001, $0.001,0.1,0.01,0.1,0.1,1,0.1,1$, and 0.01 , respectively. The calculation of CS was performed on the basis of the following equations [62].

$$
\mathrm{CS}=\mathrm{C}_{\mathrm{NaP}} \cdot \mathrm{TEF}_{\mathrm{NaP}}+\ldots+\mathrm{C}_{\mathrm{IcdP}} \cdot \mathrm{TEF}_{\mathrm{IcdP}}
$$

Other parameters in formulas are defined in Table 2. The total risk was estimated as the sum of individual risk of above three exposure pathways:

$$
\mathrm{ILCR}_{\mathrm{S}}=\mathrm{ILCRs}_{\text {Ingestion }}+\mathrm{ILCRs}_{\text {Dermal }}+\mathrm{ILCRs}_{\text {Inhalation }}
$$

This model was used to calculate the risk of local residents exposed to PAHs in soil. Cancer risks were estimated for three age groups: childhood ( $0-10$ years), adolescence (11-18 years) and adulthood (19-70 years). A value of ILCRs less than or equal to $10^{-6}$ was taken for non-significant or essentially negligible and as with some normal human activities (diagnostic X-rays or radiation), while the value of ILCRs in the range of $10^{-6}$ to $10^{-4}$ are low and means that the potential risks to human $[15,66]$.

The value of lifetime cancer risks from $\geq 10$ - 4 to $<10^{-3}$ are categorized as moderate, from $\geq 10^{-3}$ to $10^{-1}$ high $[19,66]$.

\section{Statistical Analysis}

Descriptive statistical operations like mean, median (med), range (minimum and maximum) and regression analysis were applied for the analysis of the measured data. Excel 2010 (Microsoft Office, Microsoft, Redmond, WA, USA) and SPSS 17.0 (SPSS Inc., 2007) was used to calculate descriptive statistics.

\section{Results and Discussion}

\section{Concentration of PAHs in Soil}

Descriptive statistic of PAHs from the surface soil level, deeper soil layers, as well as from all other collected samples, can be found in Table 3, Fig. 2.

All the 16 congeners of PAHs under investigation were detected at both levels, surface and in deeper 
Table 2. Parameters used for the estimation of the incremental lifetime cancer risks (ILCRs).

\begin{tabular}{|c|c|c|c|c|c|c|c|c|}
\hline \multirow{2}{*}{ Expousure parameters } & \multirow{2}{*}{ Unit } & \multicolumn{2}{|c|}{ Child } & \multicolumn{2}{|c|}{ Adolescents } & \multicolumn{2}{|c|}{ Adult } & \multirow{2}{*}{ References } \\
\hline & & M & $\mathrm{F}$ & M & $\mathrm{F}$ & M & $\mathrm{F}$ & \\
\hline Body weight (BW) & $\mathrm{kg}$ & 18.6 & 16.5 & 48.1 & 45.4 & 71.6 & 53.1 & [2] \\
\hline Exposure frequency (EF) & day/year & 350 & 350 & 350 & 350 & 350 & 350 & {$[1,2,63]$} \\
\hline Exposure duration (ED) & year & 6 & 6 & 14 & 14 & 30 & 30 & {$[64,65]$} \\
\hline Average life span (AT) & day & 25550 & 25550 & 25550 & 25550 & 25550 & 25550 & {$[2,17]$} \\
\hline Dermal surface exposure (SA) & $\mathrm{cm} 2 /$ day & 2800 & 2800 & 2800 & 2800 & 5700 & 5700 & {$[66,67]$} \\
\hline Dermal adherence factor (AF) & $\mathrm{mg} / \mathrm{cm}$ & 0.2 & 0.2 & 0.2 & 0.2 & 0.07 & 0.07 & {$[66,67]$} \\
\hline Dermal adsorption factor (ABS) & - & 0.13 & 0.13 & 0.13 & 0.13 & 0.13 & 0.13 & {$[2,67]$} \\
\hline Particle emission factor (PEF) & $\mathrm{m} 3 / \mathrm{kg}$ & $1.36 \cdot 109$ & $1.36 \cdot 109$ & $1.36 \cdot 109$ & $1.36 \cdot 109$ & $1.36 \cdot 109$ & $1.36 \cdot 109$ & {$[2,68]$} \\
\hline Ingestion rate (IRingestion) & $\mathrm{mg}$ /day & 200 & 200 & 100 & 100 & 100 & 100 & {$[2,66]$} \\
\hline Inhalation rate (IRinhalation) & $\mathrm{m} 3 /$ day & 10.9 & 10.9 & 17.7 & 17.7 & 17.7 & 17.7 & {$[63,65]$} \\
\hline $\begin{array}{l}\text { Carcinogenic slope factor ingestion } \\
\text { (CSFIngestion) }\end{array}$ & $\mathrm{mg} / \mathrm{kg} \cdot$ day & 7.3 & 7.3 & 7.3 & 7.3 & 7.3 & 7.3 & {$[16,64]$} \\
\hline $\begin{array}{l}\text { Carcinogenic slope factor dermal } \\
\text { (CSFDermal) }\end{array}$ & $\mathrm{mg} / \mathrm{kg} \cdot$ day & 25 & 25 & 25 & 25 & 25 & 25 & {$[64,68]$} \\
\hline $\begin{array}{l}\text { Carcinogenic slope factor inhalation } \\
\text { (CSFInhalation) }\end{array}$ & $\mathrm{mg} / \mathrm{kg} \cdot$ day & 3.85 & 3.85 & 3.85 & 3.85 & 3.85 & 3.85 & {$[16,64]$} \\
\hline
\end{tabular}

layer. Concentration of $\mathrm{SPAH} 16$ in industrial soil in Banja Luka ranged from 0.088 to $2.922 \mathrm{mg} / \mathrm{kg}$, with mean of $0.897 \mathrm{mg} / \mathrm{kg}$. PAHs concentration in deeper layers of soil measured between 0.098 and $0.841 \mathrm{mg} / \mathrm{kg}$, with the mean of $0.392 \mathrm{mg} / \mathrm{kg}$. PAHs concentration of surface soil measured between 0.599 and $2.848 \mathrm{mg} / \mathrm{kg}$ (mean $1.714 \mathrm{mg} / \mathrm{kg}$ ). The surface soil contains about $80 \%$ $\Sigma$ PAH16, while in the deeper soil layers the total value of 16 PAHs that were analyzed, was about $20 \%$, that is, the highest concentration of PAHs was retained in the surface layer of the soil.

The mean concentration of 16 PAHs in surface soil in industrial complex in Banja Luka showed similar results as recorded in the study of industrial soil in Tarragona County (Spain) as well (mean $\Sigma$ PAH16 $1.002 \mathrm{mg} / \mathrm{kg}$ ) [11], $\mathrm{P} A H 16$ in industrial areas of the Yangtze River Delta region (China) (mean $0.471 \mathrm{mg} / \mathrm{kg}$ ) [69]. The average $\sum 16$-PAHs in Orlando and Tampa (Florida, USA) urban soils were 3.227 and $4.562 \mathrm{mg} / \mathrm{kg}$, respectively [70], that is the concentrations of these pollutants were far higher in urban soil than in industrial soil in our study. Crnković et al. (2006) [43] in the research conducted also included residential, urban and rural zone in Belgrade (Serbia), and values of sum 16 PAHs were $0.298 \mathrm{mg} / \mathrm{kg}, 0.375 \mathrm{mg} / \mathrm{kg}$ and 0.018 $\mathrm{mg} / \mathrm{kg}$, respectively.

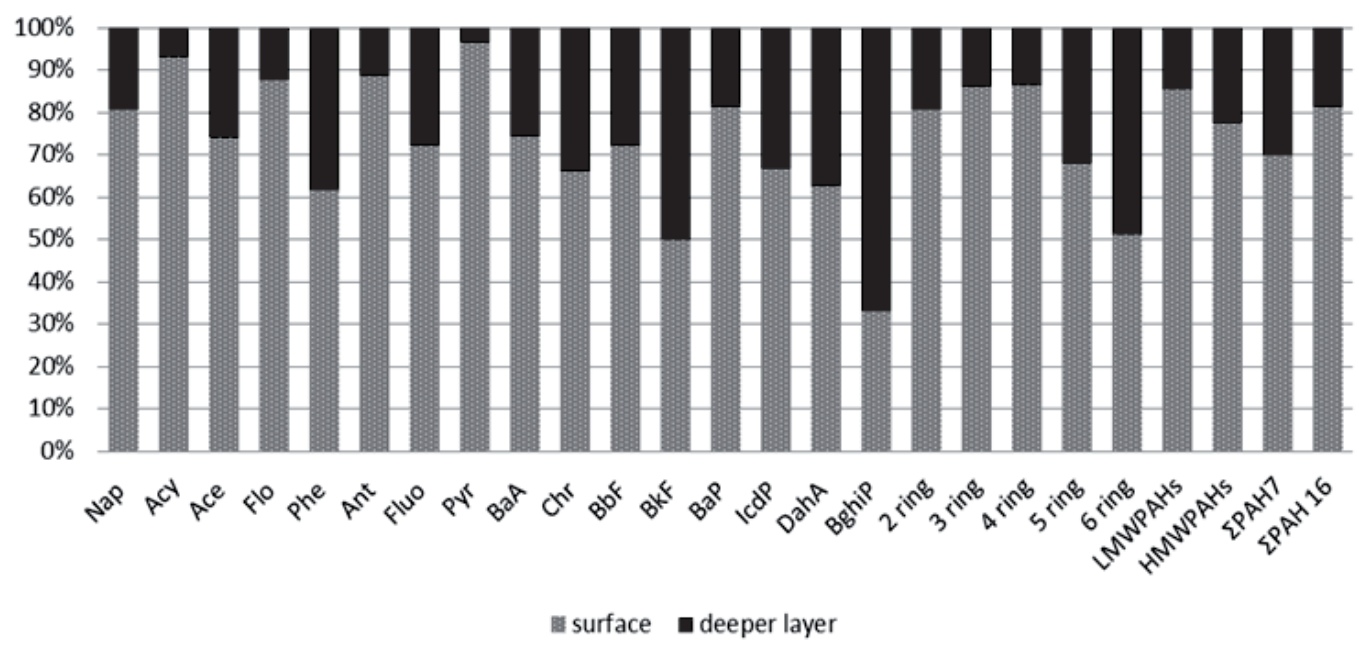

Fig. 2. Distribution of PAHs on the surface and underground layers of soil on the grounds of industrial complex in Banja Luka. 
Table 3. Concentrations of PAHs (in $\mathrm{mg} / \mathrm{kg}$ ) in soil.

\begin{tabular}{|c|c|c|c|c|c|c|}
\hline & \multicolumn{3}{|c|}{$0-30 \mathrm{~cm}$} & \multicolumn{3}{|c|}{$30-400 \mathrm{~cm}$} \\
\hline & Mean & Min & Max & Mean & Min & Max \\
\hline Nap & 0.142 & 0.083 & 0.196 & 0.034 & 0.010 & 0.071 \\
\hline Acy & 0.237 & 0.066 & 0.319 & 0.018 & 0.002 & 0.041 \\
\hline Ace & 0.091 & 0.017 & 0.239 & 0.032 & 0.010 & 0.062 \\
\hline Flo & 0.152 & 0.029 & 0.279 & 0.022 & 0.008 & 0.062 \\
\hline Phe & 0.030 & 0.010 & 0.045 & 0.019 & 0.001 & 0.091 \\
\hline Ant & 0.202 & 0.009 & 0.298 & 0.026 & 0.006 & 0.068 \\
\hline Fluo & 0.058 & 0.034 & 0.092 & 0.023 & 0.009 & 0.042 \\
\hline Pyr & 0.384 & 0.289 & 0.484 & 0.015 & 0.004 & 0.032 \\
\hline $\mathrm{BaA}$ & 0.107 & 0.017 & 0.205 & 0.037 & 0.012 & 0.062 \\
\hline $\mathrm{Chr}$ & 0.035 & 0.007 & 0.083 & 0.018 & 0.001 & 0.044 \\
\hline $\mathrm{BbF}$ & 0.059 & 0.003 & 0.102 & 0.023 & 0.005 & 0.053 \\
\hline $\mathrm{BkF}$ & 0.042 & 0.004 & 0.093 & 0.042 & 0.008 & 0.070 \\
\hline $\mathrm{BaP}$ & 0.109 & 0.010 & 0.295 & 0.025 & 0.007 & 0.043 \\
\hline IcdP & 0.034 & 0.008 & 0.068 & 0.017 & 0.002 & 0.033 \\
\hline DahA & 0.018 & 0.010 & 0.026 & 0.011 & 0.006 & 0.015 \\
\hline BghiP & 0.016 & 0.003 & 0.024 & 0.031 & 0.007 & 0.052 \\
\hline 2 ring & 0.142 & 0.083 & 0.196 & 0.034 & 0.010 & 0.071 \\
\hline 3 ring & 0.148 & 0.009 & 0.319 & 0.024 & 0.001 & 0.091 \\
\hline 4 ring & 0.146 & 0.007 & 0.484 & 0.023 & 0.001 & 0.062 \\
\hline 5 ring & 0.057 & 0.003 & 0.295 & 0.027 & 0.005 & 0.070 \\
\hline 6 ring & 0.025 & 0.003 & 0.068 & 0.024 & 0.002 & 0.052 \\
\hline LMWPAHs & 0.147 & 0.009 & 0.319 & 0.025 & 0.001 & 0.091 \\
\hline HMWPAHs & 0.086 & 0.003 & 0.484 & 0.025 & 0.001 & 0.070 \\
\hline$\Sigma$ car7PAH & 0.403 & 0.059 & 0.872 & 0.173 & 0.041 & 0.320 \\
\hline$\Sigma 16 \mathrm{PAH}$ & 1.714 & 0.599 & 2.848 & 0.392 & 0.098 & 0.841 \\
\hline
\end{tabular}

LMWPAHs - PAHs with 2 and 3 aromatic rings; HMWPAHs - PAHs with 4-6 aromatic rings; $\Sigma 7$ carPAHs - sum of BaA, Chr, BbF, $\mathrm{BkF}, \mathrm{BaP}$, IcdP, DahA; $\Sigma 16 \mathrm{PAHs}$ - sum of $16 \mathrm{PAHs}$ identified as priority environmental pollutants; TEF - Toxic equivalence factor; Beq - toxic equivalent data based on TEF value for individual PAHs

A previous study shows that the site is highly polluted with heavy metals and organic pollutants (TPH and PCB) [71] and PCB [72]. Additional research has identified two main sources of PAHs at this site: pyrogenic (coal combustion, vehicle emission and incomplete combustion), and petrogenic (from petroleum spills, probably illegal waste disposal in location) [32], with less presence and biomass combustion sources [73].

Based on the 16 USEPA priority pollutants, Maliszewska-Kordybach (1996) divided the PAHs pollution in soils into four groups [74]. A $\Sigma 16 \mathrm{PAHs}$ soil concentration below $0.2 \mathrm{mg} / \mathrm{kg}$ indicates no pollution, a concentration of $0.2-0.6 \mathrm{mg} / \mathrm{kg}$ represents light pollution, and a soil concentration of $0.6-1 \mathrm{mg} / \mathrm{kg}$ represents moderate pollution. Concentrations over $1 \mathrm{mg} / \mathrm{kg}$ would be indicative of heavy pollution [74]. According to this classification, it is worthwhile to note that 516 PAHs in surface soil samples were $1.714 \mathrm{mg} / \mathrm{kg}$ (mean value) higher than the level of heavy pollution $(1.0 \mathrm{mg} / \mathrm{kg})$. It indicated that the surface soils in this industrial complex stored a great amount of PAHs.

On the other hand, it is evident that concentration of $\Sigma$ car7PAH (BaA, Chr, BbF, BkF, BaP, IcdP, DahA) is dominant in the surface layer and is in range om 0.059 to $0.872 \mathrm{mg} / \mathrm{kg}$ (mean $0.403 \mathrm{mg} / \mathrm{kg}$ ), while deeper layers have a variation of concentration between 0.041 and $0.320 \mathrm{mg} / \mathrm{kg}$ (mean $0.173 \mathrm{mg} / \mathrm{kg}$ ). The $\Sigma$ car7PAH 

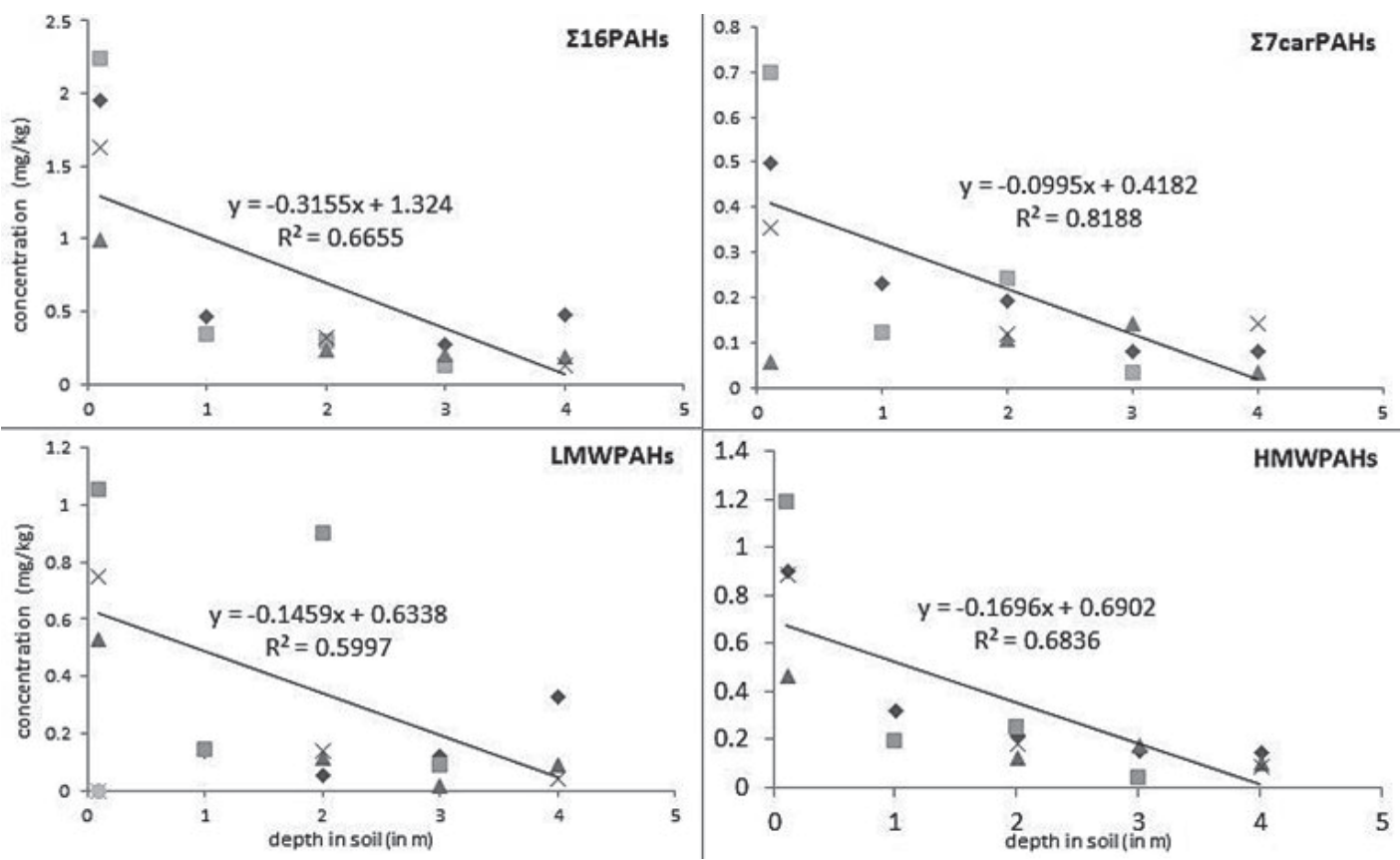

Fig. 3. Linear regression of concentration $\Sigma 16 \mathrm{PAHs}, \Sigma 7$ carPAHs, LMWPAHs and HMWPAHs at different soil depths in industrial area Banja Luka (R2 - coefficient of determination).

concentration accounted for $29-40 \%$ of $\Sigma$ PAH16. In the urban area of Naples (Italy) $\Sigma$ car7PAH ranged from 0.016 to $0.104 \mathrm{mg} / \mathrm{kg}$ (mean $0.058 \mathrm{mg} / \mathrm{kg}$ ) [75].

The detected percentages of 2-, 3-, 4-, 5- and 6-rings PAHs to the $\Sigma$ PAH16 were $27.40 \%, 28.66 \%, 28.17 \%$, $11.01 \%$, and $4.76 \%$ respectively. The concentration of low-molecular weight PAHs (LMWPAHs) in surface soil samples varied from 0.009 to $0.319 \mathrm{mg} / \mathrm{kg}$ (mean $0.147 \mathrm{mg} / \mathrm{kg}$ ), accounted for $85,46 \%$ of the LMWPAHs. The concentration of LMWPAHs in deeper layer soil samples varied from 0.001 to $0.091 \mathrm{mg} / \mathrm{kg}$ (mean $0.025 \mathrm{mg} / \mathrm{kg}$ ), accounted for $14,54 \%$ of the LMWPAHs. The decrease in concentration of LMWPAHs in deeper layer soils can be explained by facts from some studies stating that plants can degrade some of PAHs, that is LMWPAHs have higher biodegradability than the HMWPAHs [76,77], as well as that LMWPAHs in soil can be degraded by photolysis and volatilization [69]. The concentrations of high molecular weight PAHs (HMWPAHs) in surface soil varied from 0.003 to $0.484 \mathrm{mg} / \mathrm{kg}$ (mean $0,086 \mathrm{mg} / \mathrm{kg}$ ), and in deeper layer varied from 0.001 to $0.070 \mathrm{mg} / \mathrm{kg}$ (mean $0.025 \mathrm{mg} / \mathrm{kg}$ ). The HMWPAHs in surface soil accounted for $77,48 \%$, and in deeper soil layer for 22,52\% HMWPAHs.

Fig. 3 shows the linear regression, i.e., the linear regression shows the dependence of $\Sigma 16$ PAHs, $\Sigma 7$ carPAHs, LMWPAHs and HMWPAHs at different soil depths. As can be seen from the regression line equations, for all values of PAHs, the direction coefficient of the line is negative, i.e. that the concentration of PAHs decreases with increasing depth. The vertical distribution of PAHs in petroleumcontaminated soil on Loess Plateau (China) also showed a similar dependence where the concentration of $\Sigma 16$ PAHs and $\Sigma 7$ carPAHs decreased with increasing soil depth [9].

The mean concentrations $(\mathrm{mg} / \mathrm{kg})$ of individual PAHs in surface increased in the following order: BghiP $<$ DahA $<$ Phe $<$ IcdP $<$ Chr $<$ BkF $<$ Fluo $<$ BbF $<$ Ace $<$ BaA $<$ BaP $<$ Nap $<$ Flo $<$ Ant $<$ Acy $<$ Pyr; and in deeper layer the order looked as follows $\mathrm{DahA}<\mathrm{Pyr}<\mathrm{IcdP}<$ Acy $<$ Chr $<$ Phe $<$ Flo $<$ Fluo $<$ BbF $<$ BaP $<$ Ant $<$ BghiP $<$ Ace $<\mathrm{Nap}<\mathrm{BaA}<\mathrm{BkF}$. The environmental distribution and availability of PAHs, according to the literature, depend on PAHs sources and pathways, tendency to bind with organic matter, soil stability and microorganisms [78]. The surface layer is dominated by the concentration of Pyr (mean $0.384 \mathrm{mg} / \mathrm{kg}$ ) and accounted for $96.24 \%$ of total Pyr. The deeper layer of the soil is dominated by the concentration of BghiP (mean $3.10 \mathrm{mg} / \mathrm{kg}$ ) (Fig. 2).

\section{Toxicity Assessment of Pollutants}

The carcinogenic potency of PAHs was estimated using the total BaPeq (sum of $16 \mathrm{PAH}$ BaPeq) (Table 4). In this study, the total BaPeq of detected PAHs in surface soil and deeper soil layer was in the range 23.894-373.457 $\mu \mathrm{g} \mathrm{BaPeq} / \mathrm{kg}$, (mean of $154.461 \mu \mathrm{g}$ $\mathrm{BaPeq} / \mathrm{kg}$ ), and 16.514-86.521 $\mu \mathrm{g} \mathrm{BaPeq} / \mathrm{kg}$, (mean of $51.603 \mu \mathrm{g} \mathrm{BaPeq} / \mathrm{kg}$ ), respectively. The total BaPeq of seven carcinogenic PAHs in surface soil and deeper soil layer were in the range 23.270-368.63 $\mu \mathrm{g} \mathrm{BaPeq} / \mathrm{kg}$ (mean of $151.223 \mu \mathrm{g} \mathrm{BaPeq} / \mathrm{kg}$ ), and 15.71-80.24 $\mu \mathrm{g}$ $\mathrm{BaPeq} / \mathrm{kg}$, (mean of $48.08 \mu \mathrm{g} \mathrm{BaPeq} / \mathrm{kg}$ ), respectively. The total of seven carcinogenic PAHs is suggesting that the sum of those seven carcinogenic PAHs was 
Table 4. Toxic equivalence quantities of PAHs in surface and deeper soil layer (BaPeq $(\mu \mathrm{g} / \mathrm{kg}))$.

\begin{tabular}{|c|c|c|c|c|c|c|c|}
\hline & & \multicolumn{3}{|c|}{ Surface soil $(0-30 \mathrm{~cm})$} & \multicolumn{3}{|c|}{ Deeper soil $(30-400 \mathrm{~cm})$} \\
\hline & TEF & Mean & Min & Max & Mean & Min & Max \\
\hline Nap & 0.001 & 0.142 & 0.083 & 0.196 & 0.034 & 0.010 & 0.071 \\
\hline Acy & 0.001 & 0.237 & 0.066 & 0.319 & 0.018 & 0.002 & 0.041 \\
\hline Ace & 0.001 & 0.091 & 0.017 & 0.239 & 0.032 & 0.010 & 0.062 \\
\hline Flo & 0.001 & 0.152 & 0.029 & 0.279 & 0.022 & 0.008 & 0.062 \\
\hline Phe & 0.001 & 0.030 & 0.010 & 0.045 & 0.019 & 0.001 & 0.091 \\
\hline Ant & 0.01 & 2.018 & 0.090 & 2.980 & 0.260 & 0.060 & 0.680 \\
\hline Fluo & 0.001 & 0.030 & 0.010 & 0.045 & 0.023 & 0.009 & 0.042 \\
\hline Pyr & 0.001 & 0.384 & 0.289 & 0.484 & 0.015 & 0.004 & 0.032 \\
\hline $\mathrm{BaA}$ & 0.1 & 10.650 & 1.700 & 20.500 & 3.700 & 1.200 & 6.200 \\
\hline $\mathrm{Chr}$ & 0.01 & 0.348 & 0.070 & 0.830 & 0.180 & 0.010 & 0.440 \\
\hline $\mathrm{BbF}$ & 0.1 & 5.925 & 0.300 & 10.200 & 2.300 & 0.500 & 5.300 \\
\hline $\mathrm{BkF}$ & 0.1 & 4.175 & 0.400 & 9.300 & 4.200 & 0.800 & 7.000 \\
\hline $\mathrm{BaP}$ & 1 & 108.500 & 10.000 & 295.000 & 25.000 & 7.000 & 43.000 \\
\hline IcdP & 0.1 & 3.375 & 0.800 & 6.800 & 1.700 & 0.200 & 3.300 \\
\hline DahA & 1 & 18.250 & 10.000 & 26.000 & 11.000 & 6.000 & 15.000 \\
\hline BghiP & 0.01 & 0.155 & 0.030 & 0.240 & 3.100 & 0.700 & 5.200 \\
\hline इcar7PAH & - & 151.223 & 23.270 & 368.630 & 48.080 & 15.710 & 80.240 \\
\hline$\Sigma 16 \mathrm{PAH}$ & - & 154.461 & 23.894 & 373.457 & 51.603 & 16.514 & 86.521 \\
\hline
\end{tabular}

the major contributor to total BaPeq in surface soil and deeper soil samples. The total of sixteen and seven carcinogenic PAHs recorded far higher values in the surface layer compared to the deeper layers of the soil.

The contribution of PAHs to the total BaPeq in surface decreased in the order as: $\mathrm{BaP}(71.75 \%)>\mathrm{DahA}$ $(12,07 \%)>\mathrm{BaA}(7.04 \%)>\mathrm{BbF}(3,92 \%)>\mathrm{BkF}(2.76 \%)>$ $\operatorname{IcdP}(2.23 \%)>\operatorname{Chr}(0.23 \%)$.

The total BaPeq of sixteen and seven carcinogenic PAHs in surface soil were much higher than that in rural soils samples of Dongjiang River Basen, China (range $0.10-21.52 \mu \mathrm{g} / \mathrm{kg}$, mean $8.36 \mu \mathrm{g} / \mathrm{kg}$ ) [19], Naples, Italy (range 3.89-29.4 $\mu \mathrm{g} / \mathrm{kg}$ ) [75], Viseu, Portugal (mean $24 \mu \mathrm{g} / \mathrm{kg}$ ) [6] and Niger Delta, Nigeri (range 2.34-197 $\mu \mathrm{g} / \mathrm{kg}$ ) [79], while lower than in urban soils of Lisbon, Portugal (mean $229 \mu \mathrm{g} / \mathrm{kg}$ ) [6]; parkland, residential and industrial soils of Saint Petersburg, Russia (mean $440.5 \mu \mathrm{g} / \mathrm{kg}, 650.1 \mu \mathrm{g} / \mathrm{kg}$ and $544.8 \mu \mathrm{g} / \mathrm{kg}$, respectively) [80]. These indicated that PAHs in industrial soil of Banja Luka presented relatively high toxicity potency and should be taken seriously.

\section{Health Risk Assessment of PAHs}

The incremental life cancer risks (ILCRs) account for the potential health risks to different age groups caused by soil- borne PAH exposure through direct ingestion, dermal contact and inhalation collectively of soil samples collected from industrial complex Banja Luka. ILCRs of people for different exposure pathways are presented in Table 5. and Fig. 4. A value of ILCRs less than or equal to 10-6 was taken for nonsignificant on human health, the value of ILCRs in the range of $10^{-6}$ to $10^{-4}$ means that the potential risks to human; the value from $\geq 10^{-4}$ to $<10^{-3}$ are categorized as moderate, from $\geq 10^{-3}$ to $10^{-1}$ high and very high $[64,66$, 68].

The ILCRs for adolescents were less susceptible to the damage of PAHs cancer risk compared to the rest two ages group; especially children were more sensitive to the health risk of this pollutant [66]. Cancer risks for women $\left(2.21 \cdot 10^{-3}\right)$ exposed to PAHs was slightly greater than that for men $\left(1.81 \cdot 10^{-3}\right)$, however, the difference was not significant. The explanation lays in body composition and weight differences between men and women [65].

Dermal contact with soil was the most important determination for the risk level with max values of $1.74 \cdot 10^{-3}, 1.89 \cdot 10^{-3}, 2.16 \cdot 10^{-3}, 2.25 \cdot 10^{-3}, 2.53 \cdot 10^{-3}$ and $3.09 \cdot 10^{-3}$ for male and female children, for male and female adolescents and male and female adults, respectively. This corresponded to $55 \%, 56 \%, 71 \%$, $72 \%, 64 \%$ and $63 \%$ of the total risk level, respectively. Compared with children, dermal contact appeared to be 
Table 5. Incremental lifetime cancer risks (ILCRs) of people for different exposure pathways.

\begin{tabular}{|c|c|c|c|c|c|}
\hline Age range & Gender & Exposure pathway & Mean & Min & Max \\
\hline \multirow{8}{*}{ Child } & \multirow{4}{*}{ M } & Ingestion & $6.41 \mathrm{E}-04$ & $9.91 \mathrm{E}-05$ & $1.40 \mathrm{E}-03$ \\
\hline & & Dermal & 7.99E-04 & $1.24 \mathrm{E}-04$ & $1.74 \mathrm{E}-03$ \\
\hline & & Inhalation & $1.35 \mathrm{E}-08$ & 2.09E-09 & $2.96 \mathrm{E}-08$ \\
\hline & & Cancer risk & $1.44 \mathrm{E}-03$ & $2.23 \mathrm{E}-04$ & $3.14 \mathrm{E}-03$ \\
\hline & \multirow{4}{*}{$\mathrm{F}$} & Ingestion & $6.94 \mathrm{E}-04$ & $1.07 \mathrm{E}-04$ & $1.52 \mathrm{E}-03$ \\
\hline & & Dermal & $8.65 \mathrm{E}-04$ & $1.34 \mathrm{E}-04$ & $1.89 \mathrm{E}-03$ \\
\hline & & Inhalation & $1.47 \mathrm{E}-08$ & 2.27E-09 & $3.20 \mathrm{E}-08$ \\
\hline & & Cancer risk & $1.56 \mathrm{E}-03$ & $2.41 \mathrm{E}-04$ & $3.41 \mathrm{E}-03$ \\
\hline \multirow{8}{*}{ Adolescence } & \multirow{4}{*}{ M } & Ingestion & $3.97 \mathrm{E}-04$ & $6.14 \mathrm{E}-05$ & 8.67E-04 \\
\hline & & Dermal & $9.89 \mathrm{E}-04$ & $1.53 \mathrm{E}-04$ & $2.16 \mathrm{E}-03$ \\
\hline & & Inhalation & $2.72 \mathrm{E}-08$ & 4.21E-09 & $5.85 \mathrm{E}-08$ \\
\hline & & Cancer risk & $1.39 \mathrm{E}-03$ & $2.14 \mathrm{E}-04$ & $3.03 \mathrm{E}-03$ \\
\hline & \multirow{4}{*}{$\mathrm{F}$} & Ingestion & 4.12E-04 & $6.38 \mathrm{E}-05$ & $9.01 \mathrm{E}-04$ \\
\hline & & Dermal & $1.03 \mathrm{E}-03$ & $1.59 \mathrm{E}-04$ & $2.25 \mathrm{E}-03$ \\
\hline & & Inhalation & $2.83 \mathrm{E}-08$ & 4.38E-09 & $6.18 \mathrm{E}-08$ \\
\hline & & Cancer risk & $1.44 \mathrm{E}-03$ & $2.23 \mathrm{E}-04$ & $3.15 \mathrm{E}-03$ \\
\hline \multirow{8}{*}{ Adult } & \multirow{4}{*}{ M } & Ingestion & $6.52 \mathrm{E}-04$ & $1.01 \mathrm{E}-04$ & $1.42 \mathrm{E}-03$ \\
\hline & & Dermal & $1.16 \mathrm{E}-03$ & $1.79 \mathrm{E}-04$ & $2.53 \mathrm{E}-03$ \\
\hline & & Inhalation & 4.68E-08 & 7.08E-09 & $1.00 \mathrm{E}-07$ \\
\hline & & Cancer risk & $1.81 \mathrm{E}-03$ & $2.80 \mathrm{E}-04$ & $3.96 \mathrm{E}-03$ \\
\hline & \multirow{4}{*}{$\mathrm{F}$} & Ingestion & 7.96E-04 & $1.23 \mathrm{E}-04$ & $1.74 \mathrm{E}-03$ \\
\hline & & Dermal & $1.41 \mathrm{E}-03$ & 2.19E-04 & 3.09E-03 \\
\hline & & Inhalation & $5.46 \mathrm{E}-08$ & $8.45 \mathrm{E}-09$ & $1.19 \mathrm{E}-07$ \\
\hline & & Cancer risk & $2.21 \mathrm{E}-03$ & $3.42 \mathrm{E}-04$ & 4.83E-03 \\
\hline
\end{tabular}

$6.00 \mathrm{E}-03$

5.00E-03

4.00E-03

3.00E-03

$2.00 \mathrm{E}-03$

$1.00 \mathrm{E}-03$

$0.00 \mathrm{E}+00$

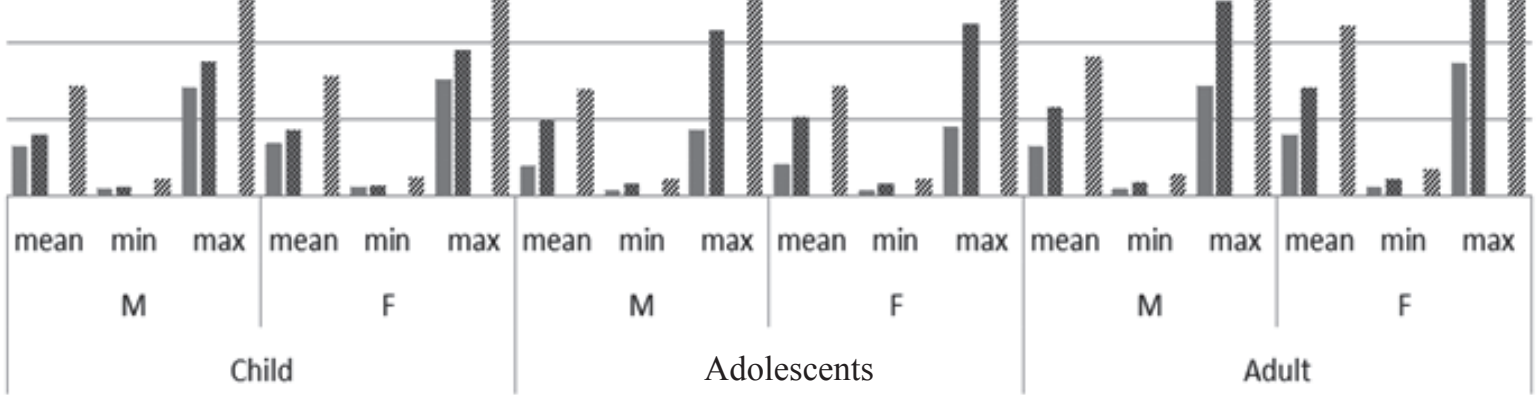

mingestion $\mathbf{m}$ dermal inhalation

Fig. 4. Cumulative probability of ILCRs by different routes of exposure of children, adolescents and adults. 
predominant exposure route with relatively higher risk for adolescents and adults. Adolescents have smaller skin surface area compared to adults, and their dermal adherence factor is larger $\left(0.2 \mathrm{mg} / \mathrm{cm}^{2}\right.$ for adolescent and only $0.07 \mathrm{mg} / \mathrm{cm}^{2}$ for adults). Similar results were reached in other studies [16,69], which showed the health risk for adults was much higher with dermal exposure compared to children. Wang et al. (2017) the reason for the higher risk is attributed to much larger skin surface the adult has, as well as much longer exposure time to pollutants [66].

The cancer risk levels via ingestion were within the same order of magnitude $\left(10^{-4}\right)$ as dose via dermal contact, indicating that the ingestion and dermal contact greatly contributed to the cancer risk for children, adolescents and adults. Mean ILCRs values for ingestion were $6.41 \cdot 10^{-4}$ and $6,94 \cdot 10^{-4}$ for male and female children, respectively, $3.97 \cdot 10^{-4}$ and $4.12 \cdot 10^{-4}$ for male and female adolescents, and $6.52 \cdot 10^{-4}$ and $7.96 \cdot 10^{-4}$ for male and female adults. The risk of direct ingestion for children was slightly lower than that for adults. Jiang et al. (2014) explained it with the assumption that children were the most sensitive subpopulation owing their hand-to-mouth activity [16], whereby polluted dust can be readily ingested, and Jiao et al. (2013) and Dreij et al. (2020) [65,44] explained that children are, by nature, way more active, and the soil ingestion can be significantly greater than that by adolescents and adults, leading to greater cancer risk caused by soil ingestion. Once PAHs are ingested, they more affect children's system and interfere with organ development and proper functioning of the central nervous system [79].

Mean values for ILCRs via inhalation were between $1.35 \cdot 10^{-8}$ and $5.46 \cdot 10^{-8}$. Therefore, inhalation of suspended particles through mouth and nose was negligible compared with other two routes.

Mean ILCRs values for cancer risks were $1.44 \cdot 10^{-3}$ and $1.56 \cdot 10^{-3}$ for male and female child, $1.39 \cdot 10^{-3}$ and $1.44 \cdot 10^{-3}$ for male and female adolescent, and $1.81 \cdot 10^{-3}$ and $2.21 \cdot 10^{-3}$ for adults. The value ILCRs were in this study from $\geq 10^{-4}$ to $<10^{-3}$ and indicates a high health risk. In present study, total cancer risk for children, adolescents and adults is higher than the baseline acceptable risk, indicating potentially high carcinogenic risk. These results suggest that children, adolescents and adults in industrial area in Banja Luka are exposed to high potential carcinogenic risk from soil via dermal contact and ingestion pathways. ILCRs values exceeding $10^{-4}$ are deemed to be of grave concern with potential health problems.

The high mortality rate in $\mathrm{BiH}$ associated with environmental pollution compared to Western European countries, as well as the increase in the number of new cancer cases in $\mathrm{BiH}$, compared to the results of this study, impose that $\mathrm{BiH}$ needs to take strong steps to protect human health and the environment. That is, to fulfill the basic principle of human rights, i.e. the right to a healthy environment.

\section{Conclusions}

To our knowledge, this is first report on the determination and human health contributors assessment of PAHs in surface and deeper layer soil samples in Banja Luka's industrial area. PAHs are ubiquitous environmental pollutants, posing potential threats to ecological environment and human health. All of the 16 congeners of PAHs under investigation were detected at both levels, surface and in deeper layers.

Concentration of $\mathrm{PAH} 16$ in industrial soli in Banja Luka ranged from 0.088 to $2,922 \mathrm{mg} / \mathrm{kg}$, with mean of $0.897 \mathrm{mg} / \mathrm{kg}$. Concentration of PAHs in deeper soil layers ranged from 0.098 to $0.841 \mathrm{mg} / \mathrm{kg}$, with mean of $0.392 \mathrm{mg} / \mathrm{kg}$. PAHs concentration on the surface level is between 0.599 and $2.848 \mathrm{mg} / \mathrm{kg}$ (mean $1.714 \mathrm{mg} / \mathrm{kg}$ ). The highest concentrations of PAHs were found at surface soil samples. Concentration of $\Sigma$ car7PAH (BaA, $\mathrm{Chr}, \mathrm{BbF}, \mathrm{BkF}, \mathrm{BaP}$, IcdP, DahA) on the surface level, expressed in percentage, is about $80 \%$, being much lower in deeper layers, about $20 \%$.

In our study, the total ILCRs ranged from $\geq 10-4$ to $<10-3$. Our results suggest that local residents and employees in the Banja Luka's industrial complex, grouped by age or gender (children, adolescents and adults) are exposed to high potential carcinogenic risk from soil via dermal and ingestion contact. This calls for mandatory and long-term monitoring of PAHs in the soil, as well as comprehensive research about adverse health factors. The government and the local residents in general, need to acknowledge the grave risks of PAHs contamination and prioritize the work on sustainable solutions to mitigate the current risks.

\section{Acknowledgments}

This research is funded by the Ministry for Scientific and Technological Development, Higher Education and Information Society of Republic of Srpska (19/6020/961-96/18) in the frame of project "Environmental assessment correlated with the environmental risks in the urban area". Present research was realized entirely with the equipment from the PSRI Institute for Protection and Ecology of the Republic of Srpska.

\section{Conflict of Interest}

The authors declare no conflict of interest.

\section{References}

1. YANG Y., WOODWARD L.A., LI Q.X., WANG J. Concentrations, source and risk assessment of polycyclic aromatic hydrocarbons in soils from Midway Atoll, North Pacific Ocean. PLoS One. 9 (1), e86441, 2014.

2. USEPA (US Environmental Protection Agency). Exposure Factors Handbook. EPA/600/R-090/052F; 2011. 
3. SUN F., LITTLEJOHN D., GIBSON M.D. Ultrasonication extraction and solid phase extraction clean-up for determination of US EPA 16 priority pollutant polycyclic aromatic hydrocarbons in soils by reversed-phase liquid chromatography with ultraviolet absorption detection. Anal. Chim. Act. 364, 1, 1998

4. WU C., ZHU H., LUO Y., WANG J. Concentrations and potential health hazards of polycyclic aromatic hydrocarbon in shallow groundwater of a metal smelting area in Southeastern China. Sci. Total Environ. 569, 1561, 2016.

5. TUE N. M, SUZUKI G, MISAKI K, VIET P. H, TAKAHASHI S, TANABE S. Aryl hydrocarbon receptor mediated activities in road dust from a metropolitan area, Hanoi-Vietnam: contribution of polycyclic aromatic hydrocarbons (PAHs) and human risk assessment. Sci. Total Environ. 491, 246, 2014.

6. CACHADA A., PATO P., ROCHA-SANTOS T., DA SILVA E.F, DUARTE A.C. Levels, sources and potential human health risks of organic pollutants in urban soils. Sci. Total Environ. 430, 184, 2012.

7. NAM J.J., THOMAS G.O., JAWARD F.M., STEINNES E., GUSTAFSSON O., JONES K.C. PAHs in background soils from Western Europe: influence of atmospheric deposition and soil organic matter. Chemosphere. 70 (9), 1596, 2008.

8. WILD S.R., JONES K.C. Polynuclear aromatic hydrocarbons in the United Kingdom environment: a preliminary source inventory and budget. Environ. Pollut. 88 (1), 91, 1995.

9. WANG D., MA J, LI H., ZHANG X. Concentration and potential ecological risk of PAHs in different layers of soil in the petroleum-contaminated areas of the Loess Plateau, China. Int. J. Environ. Res. Public Health. 15, 1785, 2018.

10. MENZIE C.A., POTOCKI B.B., SANTODONATO J. Exposure to carcinogenic PAHs in the environment. Environ. Sci. Technol. 26 (7), 1278, 1992.

11. NADAL M., SCHUHMACHER M., DOMINGO J.L. Levels of PAHs in soil and vegetation samples from Tarragona County, Spain. Environ. Pollut. 132, 1, 2004.

12. SHEN H., HUANG Y., WANG R., ZHU, D., LI, W., SHEN, G., WANG B., ZHANG Y., CHEN Y., LU Y., CHEN H., LI T., SUN K., LI B., LIU W., TAO, S. Global atmospheric emissions of polycyclic aromatic hydrocarbons from 1960 to 2008 and future predictions. Environ. Sci. Technol. 47 (12), 6415, 2013

13. United Nations. United Nations Economic Commission for Europe, Environmental Performance Reviews Series No 48, Bosnia and Herzegovina, Third Review, New York and Geneve, 2018.

14. SHEN B., WU J., ZHAO Z. Residues of organochlorine pesticides and polycyclic aromatic hydrocarbons in surface waters, soils and sediments of the Kaidu River catchment, northwest China. Int. J. Environ. Pollut. 63, 104, 2018.

15. TARAFDAR A., SINHA A. Public health risk assessment with bioaccessibility considerations for soil PAHs at oil refinery vicinity areas in India. Sci. Total Environ. 616, 1477, 2018.

16. JIANG Y., HU X., YVES U.J., ZHAN H., WU Y. Status, source and health risk assessment of polycyclic aromatic hydrocarbons in street dust of an industrial city, NW China. Ecotoxicol. Environ. Saf. 106, 11, 2014.

17. WANG W., HUANG M.J., KANG Y., WANG H.S., LEUNG A.O., CHEUNG K.C., WONG M.H. Polycyclic aromatic hydrocarbons (PAHs) in urban surface dust of Guangzhou, China: Status, sources and human health risk assessment. Sci. Total Environ. 409 (21), 4519, 2011.
18. ZHENG H., QU C., ZHANG J., TALPUR S.A., DING Y., XING X., QI S. Polycyclic aromatic hydrocarbons (PAHs) in agricultural soils from Ningde, China: Levels, sources, and human health risk assessment. Environ. Geochem. Health. 41, 907, 2019.

19. ZHENG T., RAN Y., CHEN L. Polycyclic aromatic hydrocarbons (PAHs) in rural soils of Dongjiang River Basin: occurrence, source apportionment, and potential human health risk. J. Soils Sediments. 14, 110, 2014.

20. QU C., LI B., WU H., WANG S., GIESY J.P. Multipathway assessment of human health risk posed by polycyclic aromatic hydrocarbons. Environ. Geochem. Health. 37, 587, 2015.

21. KIM K.H., JAHAN S.A., KABIR E., BROWN R.J. A review of airborne polycyclic aromatic hydrocarbons (PAHs) and their human health effects. Environ. Int. 6, 71, 2013.

22. HUSSAIN K., HOQUE R.R., BALACHANDRAN S., MEDHI S., IDRIS M.G., RAHMAN M., HUSSAIN F.L. Monitoring and risk analysis of PAHs in the environment. Handbook of environmental materials management. 1, 2018.

23. RENGARAJAN T., RAJENDRAN P., NANDAKUMAR N., LOKESHKUMAR B., RAJENDRAN P., NISHIGAKI I. Exposure to polycyclic aromatic hydrocarbons with special focus on cancer. Asian Pac. J. Trop. Biomed. 5 (3), $182,2015$.

24. ABDEL-SHAFY H.I., MANSOUR M.S. A review on polycyclic aromatic hydrocarbons: source, environmental impact, effect on human health and remediation. Egypt. J. Pet. 25 (1), 107, 2016.

25. LYON F. IARC monographs on the evaluation of carcinogenic risks to humans. Some industrial chemicals. 60, 389, 1994.

26. DYBING E., SCHWARZE P.E., NAFSTAD P., VICTORIN K., PENNING T.M. Polycyclic aromatic hydrocarbons in ambient air and cancer. Air pollution and cancer, IARC Sci. Publ. 161, 75, 2013.

27. KNAFLA A., PHILLIPPS K.A., BRECHER R.W., PETROVIC S., RICHARDSON M. Development of a dermal cancer slope factor for benzo [a] pyrene. Regul. Toxicol. Pharmacol. 45 (2), 159, 2006.

28. VÄÄNÄNEN V., HÄMEILÄ M., KALLIOKOSKI P., NYKYRI E., HEIKKILÄ P. Dermal exposure to polycyclic aromatic hydrocarbons among road pavers. Ann. Occup. Hyg. 49 (2), 167, 2005.

29. ARMSTRONG B.G., GIBBS G. Exposure-response relationship between lung cancer and polycyclic aromatic hydrocarbons (PAHs). Occup. Environ. Med. 66 (11), 740, 2009.

30. MOOLGAVKAR S.H., LUEBECK E.G., ANDERSON E.L. Estimation of unit risk for coke oven emissions. Risk Anal. 18 (6), 813, 1998.

31. SINHA R., PETERS U., CROSS A.J., KULLDORFF M., WEISSFELD J.L., PINSKY P.F., ROTHMAN N., HAYES R.B. Meat, meat cooking methods and preservation, and risk for colorectal adenoma. Cancer Res. 5 (17), 8034, 2005.

32. HSU P.C., CHEN I.Y., PAN C.H., WU K.Y., PAN M.H., CHEN J. R., CHEN C.J., CHANG-CJIEN G.P., HSU C.H., LIU C.S., WU M.T. Sperm DNA damage correlates with polycyclic aromatic hydrocarbons biomarker in coke-oven workers. Int. Arch. Occup. Environ. Health. 79 (5), 349, 2006.

33. KARAKAYA A., ATES I., YUCESOY B. Effects of occupational polycyclic aromatic hydrocarbon exposure on 
T-lymphocyte functions and natural killer cell activity in asphalt and coke oven workers. Hum. Exp. Toxicol. 23 (7), 317, 2004.

34. NIU Q., ZHANG H., LI X., LI M. Benzo [a] pyreneinduced neurobehavioral function and neurotransmitter alterations in coke oven workers. Occup. Environ. Med. 67 (7), 444, 2010.

35. ŠKAREK M., ČUPR P., BARTOŠ T., KOHOUTEK J., KLÁNOVÁ J., HOLOUBEK I.A. combined approach to the evaluation of organic air pollution - a case study of urban air in Sarajevo and Tuzla (Bosnia and Herzegovina). Sci. Total Environ. 384 (1-3), 182, 2007.

36. DE PIERI S., ARRUTI A., HUREMOVIC J., SULEJMANOVIC J., SELOVIC A., ĐORĐEVIĆ D., FERNÁNDEZ-OLMO O., GAMBARO A. PAHs in the urban air of Sarajevo: levels, sources, day/night variation, and human inhalation risk. Environ. Monit. Assess. 186 (3), 1409, 2014.

37. CARICCHIA A.M., CHIAVARINI S., PEZZA M. Polycyclic aromatic hydrocarbons in the urban atmospheric particulate matter in the city of Naples (Italy). Atmos. Environ. 33 (23), 3731, 1999.

38. ROEKENS E., DUMOLLIN J., MATHEEUSSEN C. PM10 dust and chemical characterisation of aerosols in Flanders, Belgium. WIT Trans. Ecol. Environ. 42, 699, 2000.

39. PIETROGRANDE M.C., ABBASZADE G., SCHNELLE-KREIS J., BACCO D., MERCURIALI M., ZIMMERMANN R. Seasonal variation and source estimation of organic compounds in urban aerosol of Augsburg, Germany. Environ. Pollut. 159 (7), 1861, 2011.

40. DJEDJIBEGOVIC J., MARJANOVIC A., SOBER M., SKRBO A., SINANOVIC K., LARSSEN T.R., GRUND M., FJELD E., ROGNERUD, S. Levels of persistent organic pollutants in the Neretva River (Bosnia and Herzegovina) determined by deployment of semipermeable membrane devices (SPMD). J. Environ. Sci. Health, Part B 45, 128, 2010.

41. DIRECTIVE 2008/105/EC of the European Parliament and of the Council of 16 December 2008 on environmental quality standards in the field of water policy, amending and subsequently repealing. Official Journal of the European Union. 348, 84, 2008.

42. MORILLO E., ROMERO A.S., MAQUEDA C., MADRID L., AJMONE-MARSAN F., GRCMAN H., DAVIDSON C.M., HURSTHOUSE A.S., VILLAVERDE J. Soil pollution by PAHs in urban soils: a comparison of three European cities. J. Environ. Monit. 9 (9), 1001, 2007.

43. CRNKOVIĆ D., RISTIĆ M., JOVANOVIĆ A., ANTONOVIĆ D. Levels of PAHs in the soils of Belgrade and its environs. Environ. Monit. Assess. 125, 75, 2007.

44. DREIJ K., LUNDIN L., LE BIHANIC F., LUNDSTEDT S. Polycyclic aromatic compounds in urban soils of Stockholm City: Occurrence, sources and human health risk assessment. Environ. Res. 182, 108989, 2020.

45. SAPCANIN A., CAKAL M., JACIMOVIC Z., PEHLIC E., JANCAN G. Soil pollution fingerprints of children playgrounds in Sarajevo city, Bosnia and Herzegovina. Environ. Sci. Pollut. Res. 24, 10949, 2017.

46. BUCHELI T.D., BLUM F., DESAULES A., GUSTAFSSON Ö. Polycyclic aromatic hydrocarbons, black carbon, and molecular markers in soils of Switzerland. Chemosphere. 56 (11), 1061, 2004

47. THIOMBANE M., ALBANESE S., DI BONITO M., LIMA A., ZUZOLO D., ROLANDI R., QI S., DE VIVO B. Source patterns and contamination level of polycyclic aromatic hydrocarbons (PAHs) in urban and rural areas of
Southern Italian soils. Environ. Geochem. Health. 41 (2), 507, 2019.

48. ILIĆ P., NIŠIĆ T., FAROOQI Z.U.R. Polycyclic Aromatic Hydrocarbons Contamination of Soil in an Industrial Zone and Evaluation of Pollution Sources. Pol. J. Environ. Stud. 30 (1), 155, 2021.

49. ZHAO Z., ZENG H., WU J., ZHANG L. Concentrations, sources and potential ecological risks of polycyclic aromatic hydrocarbons in soils from Tajikistan. Int. J. Environ. Pollut. 61, 13, 2017.

50. USEPA (US Environmental Protection Agency). Environmental Risk: Your Guide to Analyzing and Reducing Risk. Chicago, IL: U.S. EPA; Region 5. 1991.

51. LEAP (Local environmental action plan for the city of Banja Luka, for period 2016-2021. Banja Luka. 2015.

52. LAUNHARDT T., STREHLER A., DUMLER-GRADL R., THOMA H., VIERLE O. PCDD/F- and PAH-emission from house heating systems. Chemosphere. 37, 2013, 1998.

53. RABAJCZYK A., ZIELECKA M., MAŁOZIĘĆ D. Hazards Resulting from the Burning Wood Impregnated with Selected Chemical Compounds. Appl. Sci. 10 (17), 6093, 2020.

54. USEPA (US Environmental Protection Agency). Method 3550C-Ultrasonic Extraction. Test Methods for Evaluating Solid Waste, Physical/Chemical Methods. 3, 1, 2007.

55. USEPA (US Environmental Protection Agency). Method 8270D Semivolatile Organic Compounds by Gas Chromatography Mass Spectrometry. US Environmental Protection Agency. 2007.

56. USEPA (US Environmental Protection Agency). EPA Fact Sheet. Washington, DC: National Center for Environmental Assessment, Office of Research and Development. Environmental Protection Agency. 2008.

57. CETIN B. Investigation of PAHs, PCBs and PCNs in soils around a Heavily Industrialized Area in Kocaeli, Turkey: Concentrations, distributions, sources and toxicological effects. Sci. Total Environ. 560, 160, 2016.

58. EUROSTAT Cancer statistics - specific cancers. Available online: https://ec.europa.eu/eurostat/statistics-explained/ pdfscache/39738.pdf (accessed on 01 January 2021).

59. IARC (International Agency for Research on Cancer). World Health Organization: Cancer today. Available online: https:/gco.iarc.fr/today/data/factsheets/ populations/70-bosnia-and-herzegovina-fact-sheets.pdf (accessed on 01 January 2021).

60. EEA (European Environment Agency) Healthy environment, healthy lives: How the environment infuences health and well-being in Europe. 2020.

61. EEA (European Environment Agency). Air quality in Europe-2019 Report. 2019.

62. KUŚMIERZ M., OLESZCZUK P. Biochar production increases the polycyclic aromatic hydrocarbon content in surrounding soils and potential cancer risk. Environ. Sci. Pollut. Res. 21, 3646, 2014.

63. MOORE F., AKHBARIZADEH R., KESHAVARZI B., KHABAZI S., LAHIJANZADEH A., KERMANI M. Ecotoxicological risk of polycyclic aromatic hydrocarbons (PAHs) in urban soil of Isfahan metropolis, Iran. Environ. Monit. Assess. 187, 207, 2015.

64. CAO W., YIN L., ZHANG D., WANG Y., YUAN J., ZHU Y., DOU J. Contamination, Sources, and Health Risks Associated with Soil PAHs in Rebuilt Land from a Coking Plant, Beijing, China. Int. J. Environ. Res. Public Health 16, 670, 2019.

65. JIAO W., WANG T., KHIM J.S., LUO W., HU W., NAILE J.E., GIESY J.P., LU Y. Polycyclic aromatic hydrocarbons 
in soils along the coastal and estuarine areas of the northern Bohai and Yellow Seas, China. Environ. Monit. Assess. 185, 8185, 2013.

66. HU T., ZHANG J., YE C., ZHANG L., XING X., ZHANG, Y., WANG Y., SUN W., QI S., ZHANG Q. Status, source and health risk assessment of polycyclic aromatic hydrocarbons (PAHs) in soil from the waterlevel-fluctuation zone of the Three Gorges Reservoir, China. J. Geochem. Explor. 172, 20, 2017.

67. YU B., XIE X., MA L.Q., KAN H., ZHOU Q. Source, distribution, and health risk assessment of polycyclic aromatic hydrocarbons in urban street dust from Tianjin, China. Environ. Sci. Pollut. Res. 21, 2817, 2014.

68. SOLTANI N., KESHAVARZI B., MOORE F., TAVAKOL T., LAHIJANZADEH A.R., JAAFARZADEH N., KERMANI M. Ecological and human health hazards of heavy metals and polycyclic aromatic hydrocarbons (PAHs) in road dust of Isfahan metropolis, Iran. Sci. Total Environ. 505, 712-, 2015.

69. WANG J., ZHANG X., LING W., LIU R., LIU J., KANG F., GAO Y. Contamination and health risk assessment of PAHs in soils and crops in industrial areas of the Yangtze River Delta region, China. Chemosphere. 168, 976, 2017.

70. LIU Y., GAO P., SU J., DE OLIVEIRA L.M., TOWNSEND T., XIANG P., MA L.Q. PAHs in urban soils of two Florida cities: background concentrations, distribution, and sources. Chemosphere. 214, 220, 2019.

71. ILIĆ P., NIŠIĆ T., ILIĆ P, STOJANOVIĆ BJELIĆ LJ. Identifying New 'Hotspot' Heavy Metal Contamination in Industrial Zone Soil. Pol. J. Environ. Stud. 29 (4), 2987, 2020.

72. ILIĆ P., NIŠIĆ T., FAROOQI Z.U.R. Occurrence of Specific Polychlorinated Biphenyls Congeners in an Industrial Zone. Pol. J. Environ. Stud. 3 (1), 635, 2021.

73. ILIĆ P., NEŠKOVIĆ MARKIĆ D., STOJANOVIĆ BJELIĆ LJ., FAROOQI Z.U.R. Polycyclic Aromatic Hydrocarbons in Different Layers of Soil and Groundwater - Evaluation of Levels of Pollution and Sources of Contamination. Pol. J. Environ. Stud. 30 (1), 155, 2021.

74. MALISZEWSKA-KORDYBACH B. Polycyclic aromatic hydrocarbons in agricultural soils in Poland: preliminary proposals for criteria to evaluate the level of soil contamination. Appl. Geochem. 1 (1-2), 121-127, 1996.

75. DE NICOLA F., ALFANI A., MAISTO G. Polycyclic aromatic hydrocarbon contamination in an urban area assessed by Quercus ilex leaves and soil. Environ. Sci. Pollut. Res. 21, 7616, 2014.

76. JIAO H., BIAN G., CHEN X., WANG S., ZHUANG X., BAI Z. Distribution, sources, and potential risk of polycyclic aromatic hydrocarbons in soils from an industrial district in Shanxi, China. Environ. Sci. Pollut. Res. 24, $12243,2017$.

77. UGWU K.E., UKOHA P.O. Analysis and sources of polycyclic aromatic hydrocarbons in soil and plant samples of a coal mining area in Nigeria. Bull. Environ. Contam. Toxicol. 96 (3), 383-387, 2016.

78. GERESLASSIE T., WORKINEH A., LIU X., YAN X., WANG J. Occurrence and Ecological and Human Health Risk Assessment of Polycyclic Aromatic Hydrocarbons in Soils from Wuhan, Central China. Int. J. Environ. Res. Public Health. 15, 2751, 2018.

79. IWEGBUE C.M., OBI G., AGANBI E., OGALA J.E., OMO-IRABOR O.O., MARTINCIGH B.S. Concentrations and health risk assessment of polycyclic aromatic hydrocarbons in soils of an urban environment in the Niger Delta, Nigeria. J. Toxicol. Environ. Health Sci. 8, 221, 2016.

80. SHAMILISHVILI G., ABAKUMOV E. Organic and Inorganic Contaminants in Urban Soils of St. Petersburg (Russia). In International Congress on Soils of Urban, Industrial, Traffic, Mining and Military Areas. Springer, Cham. 51, 2017. 